Poetry

\title{
The death of the hippocratic oath-the seven principles of the hippocratic oath (and paradigm)
}

\author{
Special Issue - 2015
}

\section{Introduction}

Paradigm for the Seven Principles of the Oath:

Universal Art \& Science force mentality-

Seraphim enflamed therapy holiness immure-

Transcendental existence synthesizes entropy-

Peace and mercy care and cure.

Unity spectrum teaching medical hope identity -

Thrones' love-in-charge heard -

Twenty-five centuries of Family humanity-

Thus patients were cared for and cured.

No death but life dimensions listened to -

Principalities' socially promoted and secured -

Courage being virtue christened too-

Thus patients were cared for and cured.

Dignity event respecting the species human-

Cherubin illumine Nature matured-

Faith matter life precious proven-

Thus patients were cared for and cured.

Integrity field of spontaneity-

Dominions true freedom protected and reserved-

Sacrifice truth and charity-

Thus patients were cared for and cured.

Liberty uncertainty of helping praised-

Archangel's real family referred-

Temperance good freedom raised-

Thus patients were cared for and cured.

Spirit singularity warm and gentle for earth-

Powers all health infinity assured-

Justice beauty death-without-fear birth-

Thus patients were cared for and cured.

Identity quantum health tzars cursed-

Virtues strength to overcome legalcide bane.

Prudence oneness peace erased-

Hippocratic Oath Family fratricide slain.

\section{Samuel A Nigro M.D}

Retired,Assistant Clinical Professor Psychiatry, Case Western

Reserve University School of Medicine, USA

Correspondence: Dr. Samuel A Nigro M.D., Retired,Assistant Clinical Professor Psychiatry, Case Western Reserve University School of Medicine, 2517 Guilford Road, Cleveland Heights, Ohio 44I I8, USA, Tel 216 932-0575, Email sam@docnigro.com

Received: April 19,2014 | Published: June 16, 2015

\section{The Destruction of the Oath}

Pill counting Pharmacy Board high school muckers-

Pretend medical treatment without ethics book-

Like high school food delivery truckers-

Telling best chefs how to cook.

The bureaucracy-insurance Iagos source-

Patients a veterinarian pain-

Medical Boards without Transcendental Force-

Holy Love Treatment existence drain.

The murder by unpalatable laws-

By royalty D.C. non-medical clan-

An oppressive government filled with flaws-

A greatness-pretense crying land.

Abortion, addiction, law, pain specialists - no resisters-

Sleep with the demonic herd-

They murder their own brothers and sisters-

And do it by deed and word.

Medical care a complicated success guess-

Every patient is special exact-

The law should mind its own lying business-

Even Hippocrates knew all that.

Brain chemistry more different than peoples' faces-

Thousands of chemicals and subsystem fuels-

Neuron millions synapses billions self embraces- 
And artless law imposes the treatment rules?

Like Native Americans government paroled-

Or sailors impressed ago many years-

Royalty, KGB, Weimar Oath controlled-

Putting physicians and patients in tears.

With Stanley Milgrim suggestibility-

With Stanford Penitentiary Experiment sears-

The Law knows medical care Y to Z-

Putting physicians and patients in tears.

Public servant Darwinians gone "fittest" again-

Machiavellian ignorance ruthless cheers-

"Cops and robbers" the treatment refrain-

Putting physicians and patients in tears.

Law worship has conquered all-

Mindless bureaucracy overdose fears-

Learned Medicine and Divinity fall free fall-

Putting physicians and patients in tears.

Code books give planetary motion-

Third Parties read animal entrails_-

Pre-Hippocratic "medicine" commotion-

Insurance Iagos not curtailed.

But as earth recycles to fertile sod-

With Medical Art and Science enfutured-

By Hippocratic offspring of the healing God-

Once again patients will be cared for and cured.

The first seven quartets, after the Paradigm, respectively are the seven principles of the Oath of Hippocrates:

(Paradigm)

1. Teach and Art \& Science of Medicine and practice as one Family.

2. No death promoted.

3. Morality in concert with planetary Nature.

4. Records are always private and confidential.

5. Referral with family colleagues for patient benefit.

6. Treat all the same regardless of differences.

7. All Medicine will be cursed if the Oath is not followed.

The remaining quartets respectively are descriptions of how the Oath was destroyed:

8. Pharmacists are ignorant status-seeking pretenders of medical care.

9. Non-practicing and bureaucrat physicians are destructively in charge.
10. Legislators irrationally dictate medical care.

11. The worst physicians cooperating in the death of the Hippocratic Oath.

12. The lies of law are not applicable to the variables of medical care.

13. The innumerable treatment variables cannot rationally be dictated by law.

14. Physicians are vassals and slaves on "reservations" known now as medical facilities.

15. The psychological processes which corrupt others to do evil as in Nazi Germany.

16. Public servants as medical terrorists.

17. Law worship destroys all including the Learned Professions of Medicine and Divinity.

18. Pre-Hippocratic medicine is back with contemporary planetary motion and entrails readings.

19. Hippocrates must return

As in the opening Paradigm, each of the first seven "Hippocratic practice" quartets respectively contain appropriate metaphorical reality linkages [and unstated analogues] to

a. Basic Physics: force, spectrum, dimension, event, field, uncertainty, singularity, quantum.

b. Community Universal: pursuit of happiness/transcendentals, unity, Life, dignity, integrity, Liberty, spirituality, identity.

c. Angelic Hierarchy ("angels" are "words"): Seraphim, Thrones, Principalities, Cherubin, Dominions, Archangels, Powers, Virtues, [Guardian Angels].

d. Transcendentals: existence, identity, existence, matter, truth, good, beauty, oneness.

e. Virtues: holiness, hope, courage, faith, charity, temperance, justice, prudence.

f. Art of Medicine Therapeutic Variables: peace and mercy, selective ignoring, non-reactive listening, precious life, subdued spontaneity non-self excluded, C2-consciousness-ofconsciousness for the species, detached warmth and gentleness, affect assistance --"Make That Interaction Count", Journal of Psychology and Clinical Psychiatry, 2015, 2(3): 00072.

Full elaboration on the above is available in my books Everybody for Everybody and The Soul of the Earth.

\section{Acknowledgments}

None.

\section{Conflicts of interest}

None.

\section{Funding}

None. 